\title{
Status of Environmental Controls for Geothermal Energy Development
}




\section{DISCLAIMER}

This report was prepared as an account of work sponsored by an agency of the United States Government. Neither the United States Government nor any agency Thereof, nor any of their employees, makes any warranty, express or implied, or assumes any legal liability or responsibility for the accuracy, completeness, or usefulness of any information, apparatus, product, or process disclosed, or represents that its use would not infringe privately owned rights. Reference herein to any specific commercial product, process, or service by trade name, trademark, manufacturer, or otherwise does not necessarily constitute or imply its endorsement, recommendation, or favoring by the United States Government or any agency thereof. The views and opinions of authors expressed herein do not necessarily state or reflect those of the United States Government or any agency thereof. 


\section{DISCLAIMER}

Portions of this document may be illegible in electronic image products. Images are produced from the best available original document. 


\title{
Status of Environmental Controls for Geothermal Energy Development
}

\author{
John F. Caskey
}

May 1980

MTR-80W00142

Sponsor: Division of Geothermal Energy/ Department of Energy Contract No.: DE-AC01-79ET27224

The MITRE Corporation Metrek Division

1820 Dolley Madison Boulevard

McLean, Virginia 22102 


\section{ABSTRACT}

This report presents the initial findings and recommendations of the Environmental Controls Panel to the Interagency Geothermal Coordinating Council (IGCC). The Panel has been charged to assess the adequacy of existing environmental controls for geothermal energy systems, to review ongoing programs to develop environmental controls, and to identify controls-related research areas where redirection of federal efforts are appropriate to assure the availability of controls on a timely basis. In its deliberations, the Panel placed greatest emphasis on the use of geothermal resources for electricity generation, the application of geothermal energy receiving greatest attention today. The Panel discussed major known environmental concerns and their potential impact on the commercialization of geothermal resources, control options, regulatory considerations, and ongoing and planned research programs.

The environmental concerns reviewed in this report include: air emissions, liquid discharges, solid wastes, noise, subsidence, seismicity, and hydrological alterations. For each of these concerns a brief description of the concern, associated legislation and regulations, control approaches, federal funding trend, and the Panel's recommendations and priorities are presented. In short, the Panel recommends that controls-related research efforts be rebalanced and enhanced, with the greatest emphasis placed on controls for hydrogen sulfide $\left(\mathrm{H}_{2} \mathrm{~S}\right)$ and non- $\mathrm{H}_{2} \mathrm{~S}$ gaseous emissions, injection monitoring methods, systems to treat and use nongeothermal waters for environmental control purposes, solid waste characterization and management methods evaluation, and subsidence controls. 


\section{ACKNOWLEDGMENTS}

The author is indebted to the members of the Environmental Controls Panel, who contributed much time and effort toward developing the substance of this report. The Panel members include:

David Berg, Chairman (EPA)

Clifton McFarland, Vice-Chairman (DOE)

Robert Hartley (EPA)

Gerald Katz (DOE)

Cie Ling Chiang (USGS)

Karl Duscher (BLM)

William Spalding (USFWS)

David Allen (DOE)

Tom Ladd (DOD)

Douglas Boehm (DOE)

Ron Loose (DOE)

Robert Oliver (DOE)

William Rice (DOE)

In addition, the assistance of Engineering and Economics

Research, Incorporated, in some of the intermediate revisions of this report is gratefully acknowledged. 


\section{PREFACE}

This report was prepared by The MITRE Corporation for the Environmental Controls Panel of the Interagency Geothermal Coordinating Council. The report presents the initial findings and recommendations of the Panel regarding the status of environmental controls for geothermal energy development.

Information contained in the report was gathered largely from the members of the Panel. Final editorial changes were the responsibility of the Chairman of the Pane1. Conclusions and recommendations presented in the report are solely those of the Panel and do not necessarily reflect the opinions of The MITRE Corporation. 


\section{TABLE OF CONTENTS}

\begin{tabular}{|c|c|c|}
\hline & \multirow{2}{*}{$\begin{array}{l}\text { Page } \\
\text { viii }\end{array}$} \\
\hline LIST & OF ILLUSTRATIONS & \\
\hline LIST & OF TABLES & viii \\
\hline EXECU & JTIVE SUMMARY & ix \\
\hline 1.0 & INTRODUCTION & 1 \\
\hline 1.1 & Environmental Controls Panel & 1 \\
\hline 1.2 & Environmental Concerns & 3 \\
\hline 1.3 & Federal Environmental Controls Budget & 3 \\
\hline 2.0 & $\begin{array}{l}\text { ENVIRONMENTAL CONCERNS, ASSOCIATED LEGISLATION } \\
\text { AND REGULATIONS, AND CONTROL OPTIONS }\end{array}$ & 11 \\
\hline 2.1 & Air Emissions & 13 \\
\hline 2.2 & Liquid Discharges & 20 \\
\hline 2.3 & Solid Wastes & 24 \\
\hline 2.4 & Noise & 27 \\
\hline 2.5 & Subsidence & 29 \\
\hline 2.6 & Seismicity & 32 \\
\hline 2.7 & Hydrological Alterations & 35 \\
\hline 3.0 & RECOMMENDATIONS OF THE ENVIRONMENTAL CONTROLS PANEL & 39 \\
\hline $\begin{array}{l}3.1 \\
3.2\end{array}$ & $\begin{array}{l}\text { Priorities for Research in Environmental Controls } \\
\text { Other Recommendations }\end{array}$ & $\begin{array}{l}39 \\
44\end{array}$ \\
\hline DISTR & IBUTION LIST & 47 \\
\hline
\end{tabular}


Figure Number

$\begin{array}{ll}1-1 & \begin{array}{l}\text { Federa1 Geothermal Environmental } \\ \text { Research Program - Budget Summary }\end{array} \\ 1-2 & \begin{array}{l}\text { Federal Geothermal Environmental } \\ \text { Research Program - Controls-Related } \\ \text { Budget }\end{array} \\ 1-3 \quad & \begin{array}{l}\text { Federal Geothermal Environmental } \\ \text { Research Program - Controls-Related } \\ \text { Budget by Concern }\end{array}\end{array}$

LIST OF TABLES

$\underline{\text { Table Number }}$

$1-\mathrm{I}$

Federal Geothermal Environmental Research Program - Budget Summary by Agency

Federal Geothermal Environmental Research Program - Controls-Related Budget by Agency

$1-$ II I

Federal Geothermal Environmental Research Program - Controls-Related Budget by Concern

3-I Control-Related Research Areas by Geothermal Environmental Concern

3-II Priorities for Environmental Controls Research 


\section{EXECUTIVE SUMMARY}

The Environmental Controls Panel of the Interagency Geothermal Coordinating Council has investigated the availability of existing environmental controls for geothermal energy systems. The Panel assessed the adequacy of federal research in light of current knowledge about the major environmental concerns that may interfere with the commercialization of geothermal energy resources. The Panel examined seven categories of environmental concerns: air emissions, 1 iquid discharges, solid wastes, noise, subsidence, seismicity, and hydrological alterations.

The potential impact in each environmental category on geothermal energy commercialization, the availability of controls, regulatory considerations, and the extent and adequacy of ongoing research were considered. Finally, the Panel grouped in priority order the research areas and recommended steps to modify federal research efforts to assure the availability of controls on a timely basis.

The Panel concludes that the environmental problems associated with geothermal energy development may pose obstacles to the commercialization of geothermal resources. The concern over the environmental impact of geothermal development has already delayed or suspended activity at some sites (particularly in The Geysers area of Northern California). While air emissions, particularly hydrogen sulfide, have posed the greatest environmental concern to date, the uniqueness of each geothermal resource, the rapid pace of exploration for resources, and the complexity of geothermal fluids and discharges assure that other environmental issues will present difficulties for full use of potential geothermal energy resources in the United States.

The next several years could be critical to geothermal development, because the geothermal industry is in a dynamic state and commercial activity is just beginning at several resource sites. In addition, many environmental regulations are not yet crystallized and adequate environmental controls are not fully available. The Panel found that the interests of all parties can best be served if opportunities for industry-government cooperation are pursued. Several specific research areas are identified where additional federal resources are recommended. Federal resources could be combined with those of industry to develop and demonstrate needed environmental controls in a cost-effective and timely manner. 
The paragraphs below summarize the Panel's assessment of the current situation in each of the seven environmental areas. Following are brief discussions of federal funding trends and the Panel's recommendations for the federal environmental controls program.

\section{AIR EMISSIONS}

Because of their prevalence and offensive odor, hydrogen sulfide $\left(\mathrm{H}_{2} \mathrm{~S}\right)$ emissions are of major environmental concern in geothermal development. Emissions occur during well drilling, venting and cleanout, power plant operation and steam stacking (the release of steam at vapor-dominated geothermal resources during turbine shutdown). A few states (e.g, California, New Mexico, and Hawaii) have established ambient $\mathrm{H}_{2} \mathrm{~S}$ standards, although the federal government has not done so. The state standards that currently exist are based upon odor, but are not uniform.

The Environmental Protection Agency (EPA), under authority of the Clean Air Act, may establish New Source Performance Standards (NSPS) for geothermal $\mathrm{H}_{2} \mathrm{~S}$ or other air emissions and may require the application of best available control technology (BACT). BACT is determined on a case-by-case basis as a result of existing regulations for prevention of significant deterioration (PSD) of air quality under certain conditions. In response to a recent court decision, however, EPA has proposed comprehensive amendments to the PSD regulations (see 44FR 51924, September 5, 1979). Among them is a provision that would in effect exempt from the BACT requirement, as well as other PSD requirements, any source that would emit only noncriteria pollutants in major amounts (44FR 51953-54 \& 52.21(i)(8)). A geothermal power plant would emit only $\mathrm{H}_{2} \mathrm{~S}$, a noncriteria pollutant, in major amounts, if current indications hold true. Whether EPA will make this provision final is as yet uncertain.

Insufficient data have been released to establish the environmental significance of other air emissions from geothermal energy systems. Industry sources and government researchers have, however, indicated their concern that controls may eventually be required for some or all of the following emissions: carbon monoxide, ammonia, hydrocarbons, mercury, boron, and radon.

Hydrogen sulfide control technologies have been demonstrated for geothermal operations only at The Geyers power generation site. Existing control systems, utilized downstream of the turbine, are the Iron Catalyst System (and its variants) and the Stretford process; neither has been as effective as anticipated. The upstream EIC Copper Sulfate Catalyst Process (recently demonstrated at one-tenth scale) has advantages over existing systems in that it may control 
steam stacking of $\mathrm{H}_{2} \mathrm{~S}$ emissions and may also control emissions of ammonia and boron. The system appears to be effective and costcompetitive. If commercial operation meets expectations, the EIC process may provide an acceptable control technology solution to the $\mathrm{H}_{2} \mathrm{~S}$ emission problem.

In spite of optimision regarding the EIC process, long-term reliability, economic commercial operation, and high efficiency of hydrogen sulfide abatement systems have not yet been assured for any control technology. Research, development and demonstration of new and improved technologies by both government and industry should continue at a substantial level until a solution is conclusively demonstrated.

\section{LIQUID DISCHARGES}

The main source of waste water from geothermal operations at liquid-dominated fields will be the geothermal fluid itself, principally spent brine with much lesser amounts of condensate/cooling water. Environmental problems associated with water discharges include possible contamination by dissolved metals and other substances, of surface or ground waters that might be used for drinking (by people and/or animals) or other purposes. In most cases, the waste will likely be reinjected to the subsurface. Injection not only is a disposal method, but may help to control subsidence and slow resource depletion. Under certain conditions, however, injection may also induce seismicity. In some cases surface discharge of the waste water may be allowable and more desirable, particularly where the waste water is of relatively high quality and/or water is in short supply.

Surface water discharges will be controlled mainly by National Pollution Discharge Elimination System (NPDES) permits under the Federal Water Pollution Control Act. Permit conditions will be based upon Effluent Guidelines (yet to be developed for geothermal), or upon receiving Water Quality Standards, if the technology-based guidelines are not sufficient to protect the receiving water.

Subsurface injection will be regulated by state-issued injection permits under authority delegated by EPA via the Federal Safe Drinking Water Act. The State Underground Injection Control Program regulations are now in the proposal stage. The requirements are likely to be similar to those already in effect in many states, requiring prior geologic and hydrologic studies, specific well construction procedures, and subsequent ground water monitoring. Injection regulations ordinarily require confinement rather than treatment. 
Water treatment technologies for surface disposal applicable to geothermal waste waters are likely to be adapted from other industries. The only affordable treatment for pollution control is likely to be settling, filtration and limited chemical precipitation. More elaborate treatment may be applied to obtain a saleable product or to provide fresh water where such is at a premium.

Simple conventional treatment, including chemical additives, can be applied to spent brine prior to injection to reduce the possibility of scaling and plugging in the injection system and the receiving formation. Long-term injection of geothermal spent fluids at very high flow rates poses many uncertainties that should be investigated. Injection well construction integrity procedures are probably adequate. However, system and formation compatibility must be assured, and monitoring methodologies must be developed, to assure that injected materials do not leave their zone of confinement to pollute other aquifers.

\section{$\underline{\text { SOLID WASTES }}$}

Solid wastes from geothermal operations have taken on increased importance because of their largely unknown character and the possibility that they may be classified as hazardous wastes according to criteria in regulations proposed under the Resource Conservation and Recovery Act (RCRA) of 1976. Principal sources of solid wastes from geothermal energy include drilling muds, wastewater treatment sludges, and sludges from air emission treatment.

Geothermal solid wastes (air and water treatment residuals and drilling wastes) perhaps may be temporarily exempted from the hazardous waste regulations due to amendment of RCRA. If found to be nonhazardous, they will be regulated under Subtitle D of the Act (as implemented by the individual states) which addresses nonhazardous wastes.

Waste management technolgies, such as secured landfilling, a1ready required by some states, may be available for geothermal solid waste disposal, although evaluations of these practices must be undertaken. The principal needs to be addressed are: 1) characterizing the wastes, and 2) assessing waste management techniques. An additional developmental tasks is finding sites within a reasonable distance from the geothermal operation. The costs of disposal are likely to be high, although the recovery of minerals (e.g., silver and lithium) in commercial quantities may in part offset these costs. If the geothermal wastes are classified as hazardous under the Resource Conservation and Recovery Act, disposal management costs in some cases may be restrictive. 
Noise from geothermal operations may be excessive, particularly from well drilling and steam venting. Other noise sources include well cleanout and flow testing and generating unit operations. Noise emissions will generally be regulated at the state and local level. Occupational Safety and Health Act (OSHA) regulations may require ear protection for workers at geothermal operations. The Federal Noise Control Act does not specifically control geothermal sources but does foster control of noise from federal facilities. The United States Geological Survey (USGS) limits noise from geothermal operations on leased federal land.

Controls (shields and mufflers) are considered available at reasonable cost for meeting standards that may be applied. Federally funded research and development in geothermal noise control technology development does not appear warranted.

\section{$\underline{\text { SUBS IDENCE }}$}

Subsidence may occur following the removal of large amounts of fluid from geothermal reservoirs. Subsidence may be limited by injection of the geothermal fluid or other available waters. Alternatively, production $c$ an be terminated or reduced if unacceptable levels of subsidence are detected or predicted.

Federal lessees are required to survey the land surface prior to production and to monitor the land during production. If subsidence is determined to present a significant hazard to operations or adjoining land uses, the USGS may require injection or other remedial action. Some state and local governments may also require injection if subsidence is of concern.

Research has been initiated to develop the capability to predict induced subsidence, so that remedial actions may be taken before subsidence occurs at the surface. This effort should continue at its present level.

\section{SEISMICITY}

Studies have shown that high pressure injection of large volumes of geothermal fluid can increase the frequency of microseismic events. It is not known, however, at what pressures and volumes the frequency of events will increase or whether a major earthquake can result from the lubrication of a fault. If care is taken in site selection and monitoring is performed during operations, the impacts of induced seismicity can be minimized. 
Public agencies may initiate the installation of seismic networks in producing geothermal areas for the purpose of detecting induced seismicity; federal leesees are required to cooperate with appropriate public agencies. Where induced seismicity is determined to present a significant hazard, the USGS may require remedial actions on federal lands, such as reduced production rates, reduced injection of wastes and other fluids, or suspension of production. Federal funding of research for seismic identification and monitoring is needed at a nominal level.

\section{HYDROLOGICAL ALTERATIONS}

The possible effect of geothermal development on geologic formations and their hydrologic communication has brought significant environmental concern, particularly in the proximity of Yellowstone Park. It is suspected that geothermal development may affect surface features such as hot springs, fumaroles, mud pots, and geysers or may deplete reservoirs utilized for drinking water or agricultural purposes.

There are no specific regulations controlling possible hydrological alterations caused by geothermal development. However, the National Environmental Policy Act requires evaluation of the impacts of geothermal development on unique features, such as hot springs or shallow ground water. Legislation requiring protection of hot springs and hydrological evaluation prior to leasing of certain unique lands is being proposed by state and federal governments.

If proposed legislation is enacted, hydrological evaluations may be required of proposed geothermal development sites. The cost of those evaluations may be significant enough to cause development of some sites to become uneconomical. If the evaluations indicate that a significant impact is likely, the proposed site will not be developed. The Panel is not prepared at this time to recommend significantly increased efforts aimed specifically at developing predictive tools for hydrological alterations. Further study is, however, required of the area in anticipation of future legislative mandates.

\section{FEDERAL FUNDING TRENDS}

Aggregate federal funding for environmental controls-related research has declined from fiscal year (FY) 1979 to FY 1980. Following a gradual increase to slightly over $\$ 5$ million in FY 1979, the planned funding for controls-related research has dropped over 45 percent to under $\$ 3$ million for FY 1980. Similarly, the federal funding for all geothermal environmental research has dropped sharply from $\$ 9.4$ million in FY 1979 to $\$ 5.55$ million in FY 1980 . 
The Department of Energy's (DOE) funding as a fraction of total federal spending for controls research declined from two-thirds in FY 1979 to less than one-half in FY 1980. Other agencies sponsoring environmental controls studies include the Environmental Protection Agency (EPA) and the United States Geological Survey (USGS) of the Department of Interior (DOI).

The research areas receiving greatest funding attention in FY 1978 and FY 1979 included air emissions, liquid discharges, subsidence, seismicity, and hydrological alterations. The declining federal funding for environmental controls-related research has caused funding reductions for FY 1980 in all of these research areas except seismicity. The most severe reduction (approximately 85 percent) has been in the area of air emissions, reflecting only in part the completion of the government-industry costs shared EIC $\mathrm{H}_{2} \mathrm{~S}$ abatment demonstration at The Geysers. Geothermal solid wastes have not been the object of significant federal research between FY 1977 and FY 1980 .

\section{RECOMMENDATIONS}

The Panel recommends increasing federal support for geothermal environmental controls research in a number of specific areas, some of which are among the most critical for geothermal commercialization. In the absence of increased federal funding, delays in commercialization may result from the lack of adequate controls and from uncertainties brought about by regulatory delay and/or revision. Equally important, without needed research, unacceptable environmental damage may result.

The Panel concluded that several categories of environmental concern stand out in both importance and priority for research. These are air emissions, liquid discharges, solid wastes, and subsidence. Other categories -- induced seismicity, hydrological alteration, and noise -- were deemed to warrant significant, but lesser, attention in federal research programs. Industry experts consulted by the Panel agreed with the Panel's general conclusions and most of the Panel's specific recommendations. Where differences exist, they may be attributed primarily to the longer-term perspective of federal agencies with regulatory and leasing responsibilities.

Specifically, the Pannel recommends:

1. Continued coordination among key federal agencies in conducting controls development and other controls-related research. 
2. Government monitoring of production sites on a continuing, cooperative basis for the purpose of developing a better understanding of environmental concerns and controls.

3. Overal1, increased federal funding for environmental controls research.

4. Reordering research priorities, with enhanced funding for several high priority controls development research areas including:

- accelerated development and demonstration of controls for hydrogen sulfide emissions to the atmosphere from electricity generating plants

- accelerated development and demonstration of $\mathrm{H}_{2} \mathrm{~S}$ steam stacking and well emissions control

- characterization and development of controls, where necessary, for emissions to the atmosphere of other (non $\mathrm{H}_{2} \mathrm{~S}$ ) substances

- development and demonstration of viable injection monitoring systems for liquid discharges

- research into the treatment and use of nongeothermal waters for injection to prevent subsidence and reservoir depletion

- characterization of solid wastes from geothermal energy production

- evaluation of available control (disposal) methods for solid residuals, whether hazardous or nonhazardous in nature

- development of alternative subsidence prediction, control, and prevention methods.

5. Moderate efforts in several environmental controls research areas including:

- development of brine treatment technologies

- development of in-1ine monitoring devices to measure fluid characteristics at various points in the fluid distribution and conversion system 
- development of capability to chemically and physically model and to simulate geothermal fluid during production, conversion, and injection

- development of solid waste management controls, as needed

- characterization of induced subsidence

- identification and characterization of induced seismicity

- characterization (and possible control) of radionuclide emissions.

6. Low-level efforts in the following areas:

- development of controls for induced seismicity

- development of noise controls. 


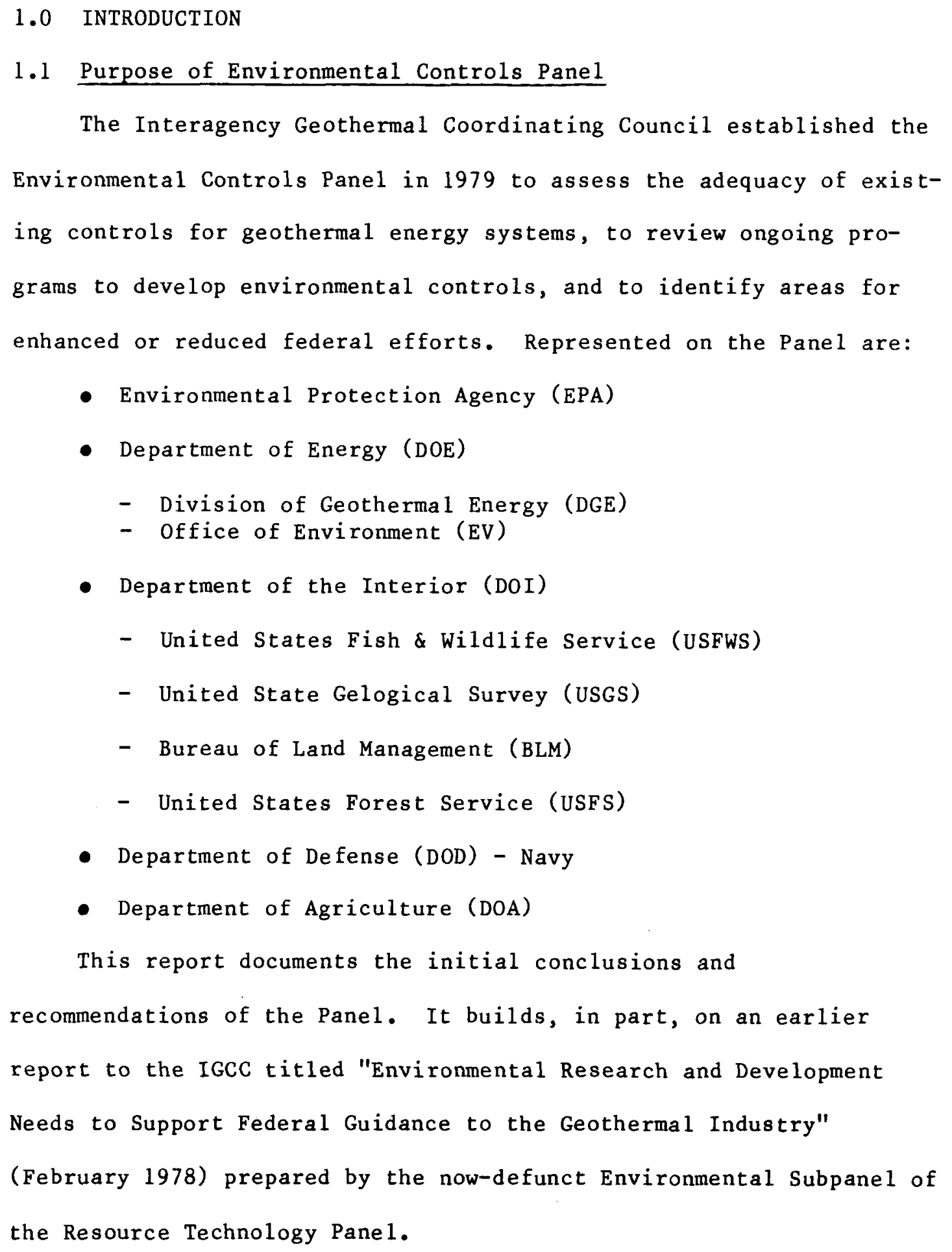

- Environmental Protection Agency (EPA)

- Department of Energy (DOE)

- Division of Geothermal Energy (DGE)

- Office of Environment (EV)

- Department of the Interior (DOI)

- United States Fish \& Wildlife Service (USFWS)

- United State Gelogical Survey (USGS)

- Bureau of Land Management (BLM)

- United States Forest Service (USFS)

- Department of Defense (DOD) - Navy

- Department of Agriculture (DOA)

This report documents the initial conclusions and recommendations of the Panel. It builds, in part, on an earlier report to the IGCC titled "Environmental Research and Development Needs to Support Federal Guidance to the Geothermal Industry" (February 1978) prepared by the now-defunct Environmental Subpanel of the Resource Technology Pane1. 
For the purpose of its work, the Panel has defined "controls" to be a technological or other method to reduce, terminate, or prevent detrimental effects on the environment. Technological controls, for example, are being used to remove $\mathrm{H}_{2} \mathrm{~S}$ from vented air emissions, to muffle noise, and to remove contaminants from water discharges. The Panel has also included in its review a limited number of controloriented support efforts (such as the definitional work in characterizing solid wastes and evaluating solid waste disposal options required to develop regulations). In addition, non-technological control methods have been included: well monitoring, for example, because the only known way to protect an aquifer is to cease injection when contamination or the threat of contamination is detected. Finally, siting is included because, for example, proper location of production facilities may prevent noise pollution from affecting other dedicated land uses and human inhabitants.

The tasks required to fulfill the stated charter of the Environmental Controls Panel are:

1) identifying the environmental concerns which may interfere with the commercialization of geothermal energy resources

2) assessing the need for controlling the impact of these concerns based on current knowledge about environmental impacts and existing and anticipated regulations

3) assessing the adequacy of existing technological and nontechnological control techniques

4) reviewing ongoing federal research efforts

5) recommending needed modification to federal research programs to assure the availability of adequate controls on a timely basis. 


\subsection{Environmental Concerns}

The major environmental concerns associated with geothermal energy development and utilization include air emissions, 1iquid discharges, solid wastes, noise, subsidence, seismicity, and hydrological alterations. Each of these concerns is discussed briefly in Section 2 of this report, together with the associated legislation and regulations, available and potential control options, and the Panel's conclusions and recommendations for federal research.

Section 3 of this report recommends the priorities for federal controls research. Sixteen research areas, identified in conjunction with industry experts, are defined and ranked in importance.

\subsection{Federal Environmental Controls Budget}

As part of its charter, the Environmental Controls Panel was charged with assessing the adequacy of existing federal funding for geothermal environmental controls-related research. The Panel has found a significant decline in federal funding for fiscal year (FY) 1980 in both the total geothermal environmental research budget and the envirnmental controls-related research budget.

Federal funding for geothermal environmental research for the years FY 1977 through FY 1980 is presented in Table 1-I and Figure 1-1. The budget amounts presented here and in later tables and figures are estimates and can only be used to illustrate the relative trends in federal funding. The funding trend for environmental research in Table $1-I$ and Figure 1-1 reflects a slight decline from 
TABLE $1-\mathrm{I}$

FEDERAL GEOTHERMAL ENVIRONMENTAL RESEARCH PROGRAM BUDGET SUMMARY BY AGENCY 1

(Thousands of dollars)

\begin{tabular}{|c|c|c|c|c|}
\hline & 1977 & 1978 & 1979 & 1980 \\
\hline$\overline{\mathrm{EPA}}$ & 700 & 850 & 850 & 850 \\
\hline DOI (USGS) & 1,000 & 1,000 & 1,250 & 1,150 \\
\hline DOE & 5,050 & 7,650 & 7,300 & 3,550 \\
\hline $\begin{array}{l}(\mathrm{DOE} / \mathrm{EV})^{2} \\
(\mathrm{DOE} / \mathrm{ET})^{2} \\
\end{array}$ & $\begin{array}{r}(3,700) \\
(1,350) \\
\end{array}$ & $\begin{array}{r}(4,400) \\
(3,250) \\
\end{array}$ & $\begin{array}{r}(3,400) \\
(3,900) \\
\end{array}$ & $\begin{array}{l}(2,300) \\
(1,250) \\
\end{array}$ \\
\hline TOTAL & 6,750 & 9,500 & 9,400 & 5,550 \\
\hline
\end{tabular}

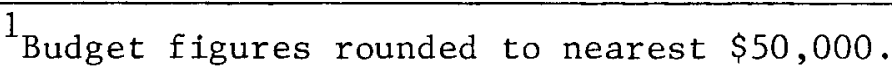

${ }^{2}$ DOE/EV - Department of Energy/Environment

DOE/ET - Department of Energy/Energy Technology
}

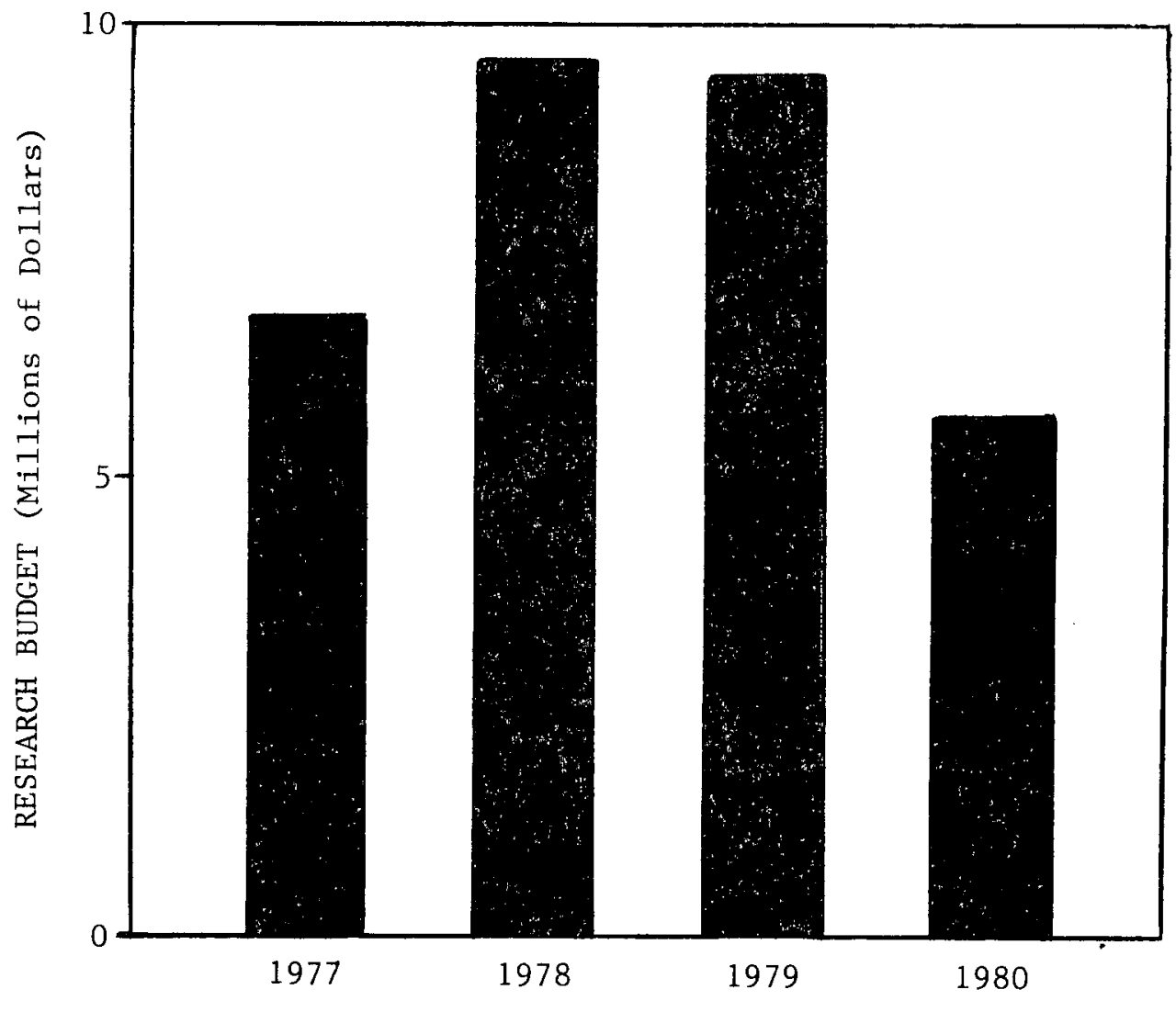

FIGURE 1-1

FEDERAL GEOTHERMAL ENVIRONMENTAL RESEARCH PROGRAM BUDGET SUMMARY 
FY 1978 to FY 1979 and then a sharp decline from FY 1979 to FY 1980. The sharp decline represents a 40 percent reduction in planned federal funding from approximately $\$ 9.4$ million in FY 1979 to $\$ 5.5$ million in FY 1980. Table 1-I also shows the preeminent role of the Deparment of Energy (DOE) in geothermal environmental research. Similarly, Table 1-II and Figure 1-2 chart a sharp decline in federal funding for controls-related research from FY 1979 to FY 1980. This sharp decline represents a 46 percent decrease in federal controls research from approximately $\$ 5.1$ million in FY 1979 to approximately $\$ 2.7$ million in FY 1980. Table $1-I I$ also shows that the DOE is the source of $\$ 2.25$ million of the $\$ 2.35$ million reduction, while the Envrionmental Protection Agency (EPA) and the United States Geological Survey (USGS) funding of controls-related research remained relatively constant from FY 1979 to FY 1980.

The federal funding trends for controls-related research by environmental concern are presented in Table l-III and Figure 1-3. Federal funding declined in FY 1980 for the environmental concerns of air emissions, liquid discharges, noise, subsidence, seismicity, and hydrological alterations. The most severe decline (approximatly 85 percent) is in the area of air emissions, though much of the decline reflects completion of construction at the government-industry costshared pilot plant demonstration of the EIC $\mathrm{H}_{2} \mathrm{~S}$ abatement process. Funding in the area of liquid discharges also declines noticably in FY 1980 by approximately 48 percent from the FY 1979 level. 
TABLE 1 -II

FEDERAL GEOTHERMAL ENVIRONMENTAL RESEARCH PROGRAM CONTROLS-RELATED BUDGET BY AGENCY ${ }^{1}$

(Thousands of dollars)

\begin{tabular}{ll}
\hline EPA & \\
DOI (USGS) \\
DOE & \\
& $(\mathrm{DOE} / \mathrm{EV})^{2}$ \\
& $(\mathrm{DOE} / \mathrm{ET})^{2}$
\end{tabular}

$\frac{1977}{300}$

$\frac{1978}{550}$

$\frac{1979}{500}$

$\frac{1980}{500}$

800

1,000

1,250

1,150

2,650

3,350

1,100

$(\mathrm{DOE} / \mathrm{ET})^{2}$

(300)

(500)

$(600)$
$(2,050)$

(200)

$(800)$

TOTAL

2,100

4,200

5,100

2,750

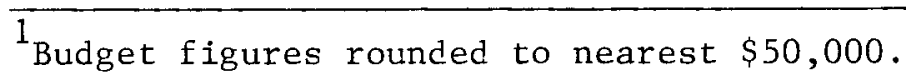

2 DOE/EV - Department of Energy/Environment

DOE/ET - Department of Energy/Energy Technology

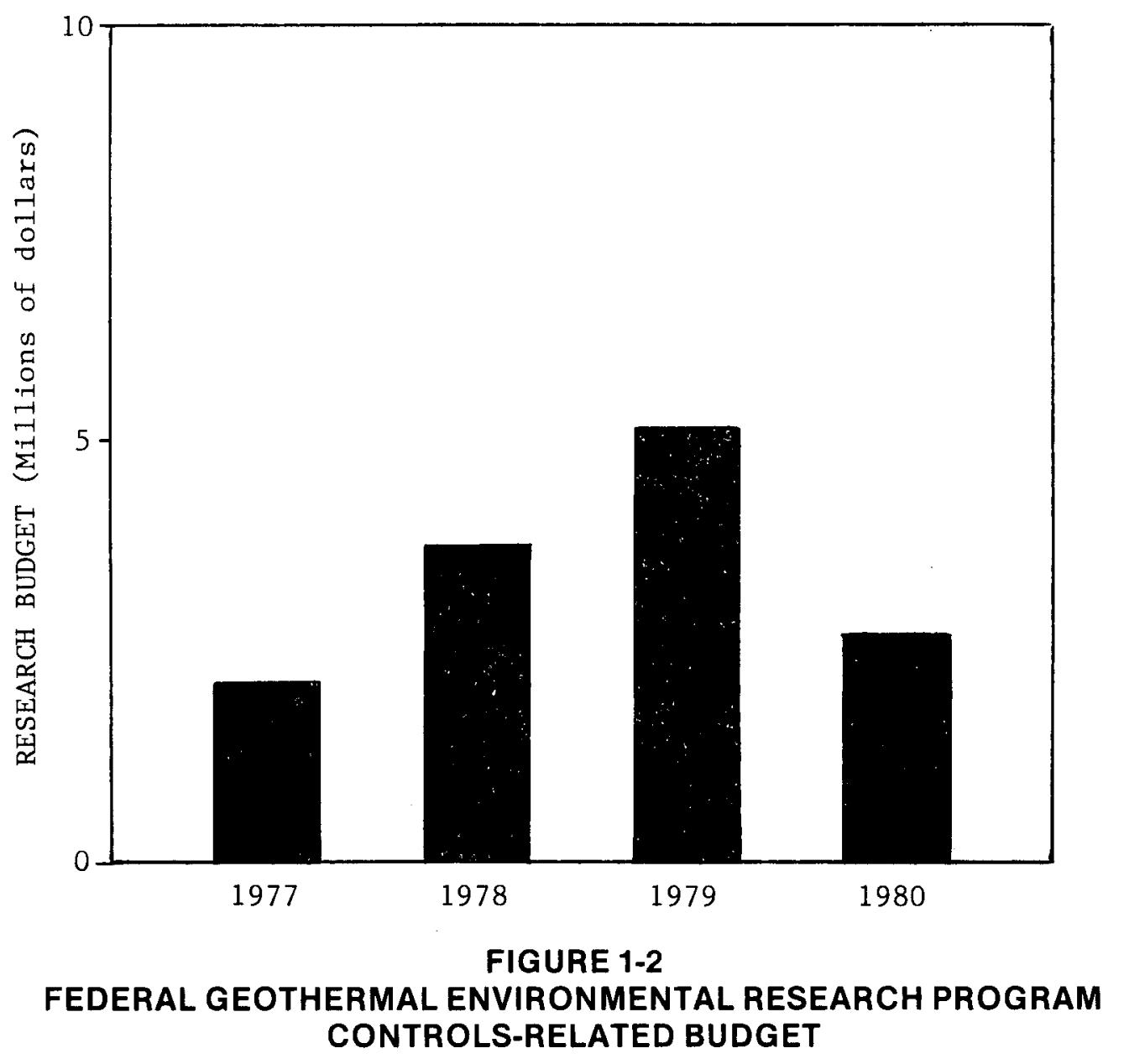


TABLE 1-III

FEDERAL GEOTHERMAL ENVIRONMENTAL RESEARCH PROGRAM CONTROLS-RELATED BUDGET BY CONCERN 1

(Thousands of dollars)

Air Emissions

$$
\text { Fiscal Year } 1977 \quad \underline{1978} \quad \underline{1979} \quad \underline{1980}
$$

Control Technology Development and Assessment

Subtotal

\begin{tabular}{rrrr}
450 & 1,350 & 1,050 & 150 \\
\hline 450 & 1,350 & 1,050 & 150
\end{tabular}

Liquid Discharges

Model Development

Underground Monitoring

$\begin{array}{llll}-- & 50 & 50 & 100\end{array}$

Control Technology Assessment

Containment Cement Development

Subtotal

\begin{tabular}{crrc}
-- & 50 & 50 & 100 \\
150 & 150 & 150 & 150 \\
300 & 400 & 250 & 300 \\
-- & 700 & 600 & --- \\
\hline 450 & 1,300 & 1,050 & 550
\end{tabular}

Solid Wastes

Characterization

Disposal Technology

Assessment

Subtotal

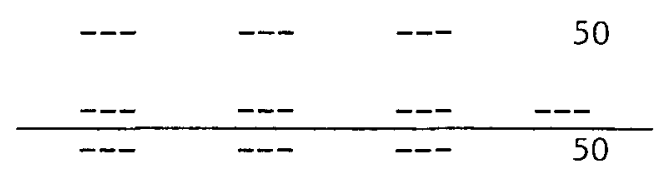

Noise

Control Technology Assessment Subtotal

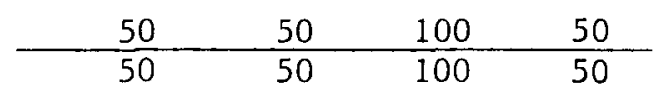

Subsidence

Predictive Model Development

Site Monitoring 2

Control Development

Sub tota1

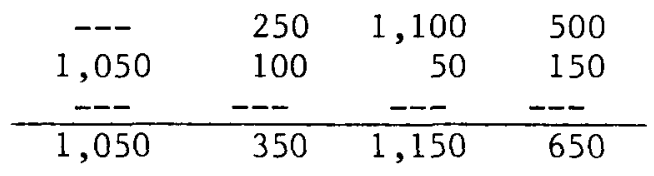

Seismicity

Site Monitoring

Control Assessment and

Development

Subtota?.

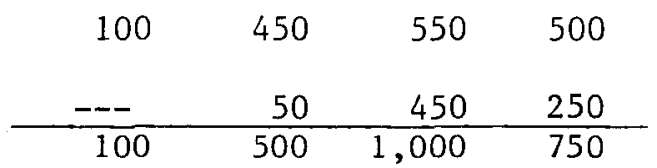

Hydrologica1 Alterations

Predictive Model Development

Site Measurement

Subtotal

\begin{tabular}{crrr}
--- & 100 & 100 & 100 \\
--- & 550 & 650 & 450 \\
\hline-- & 650 & 750 & 550 \\
\hline 2,100 & 4,200 & 5,100 & 2,750
\end{tabular}

TOTAL

$1_{\text {Budget figures rounded to nearest }} \$ 50,000$.

2

USGS seismic monitoring networks are initially for resource characterization purposes. Upon completion of the resource evaluation, the networks are used for environmental monitoring. 


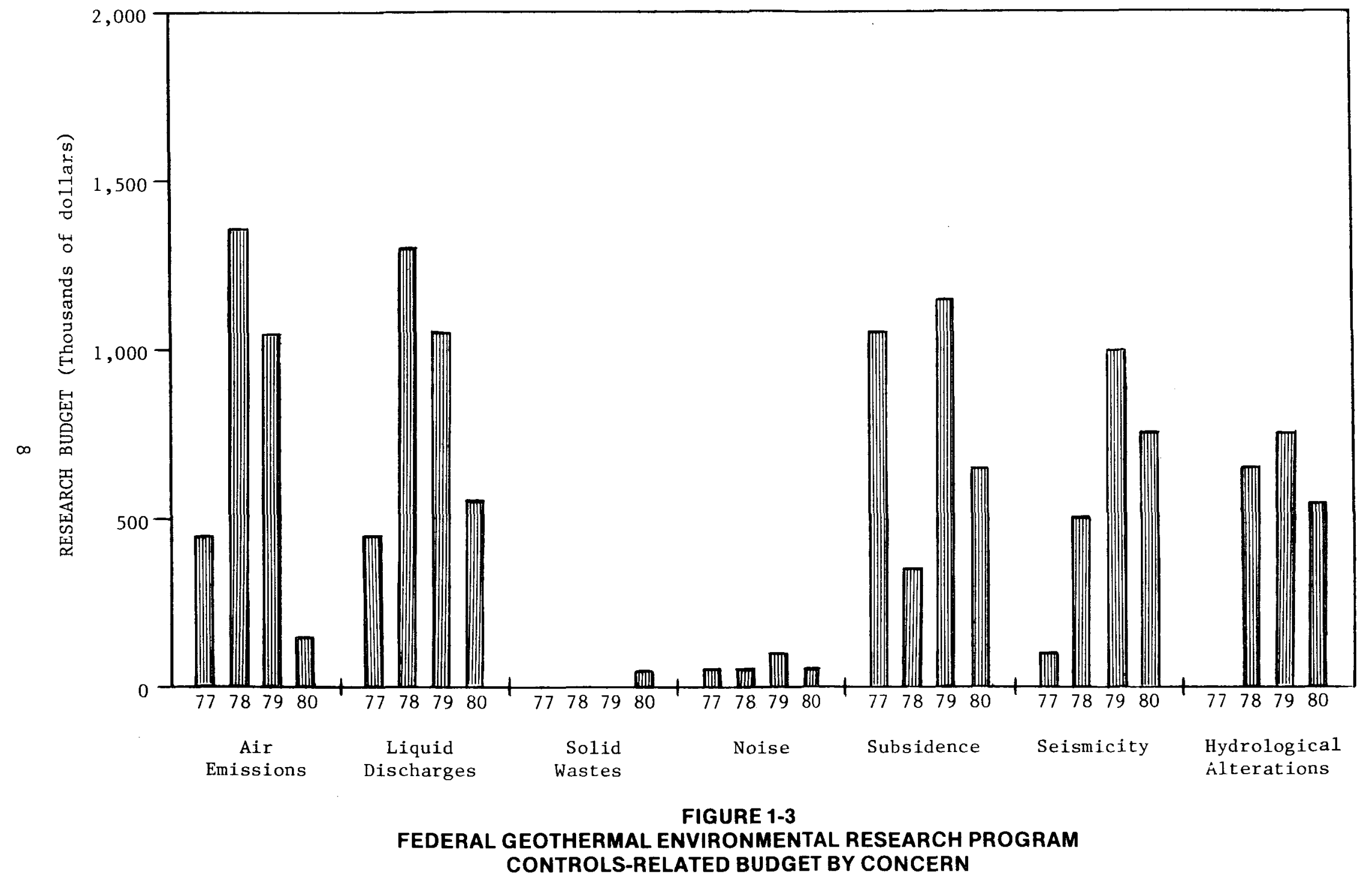


Funding for seismicity controls research is reduced 25 percent between FY 1979 and FY 1980. Funding for noise control research declined by 50 percent between FY 1979 and FY 1980, although the level of support is very low. Table l-III also shows almost no federal support for the area of solid waste characterization and control, an area of great environmental concern.

In short, the Panel found the federal funding trends for overall geothermal environmental research, controls-related research, and six of the seven environmental concerns research to be declining sharply from FY 1979 to FY 1980. In addition, the areas of air emissions and liquid discharges have declining budget trends starting in FY 1978. 


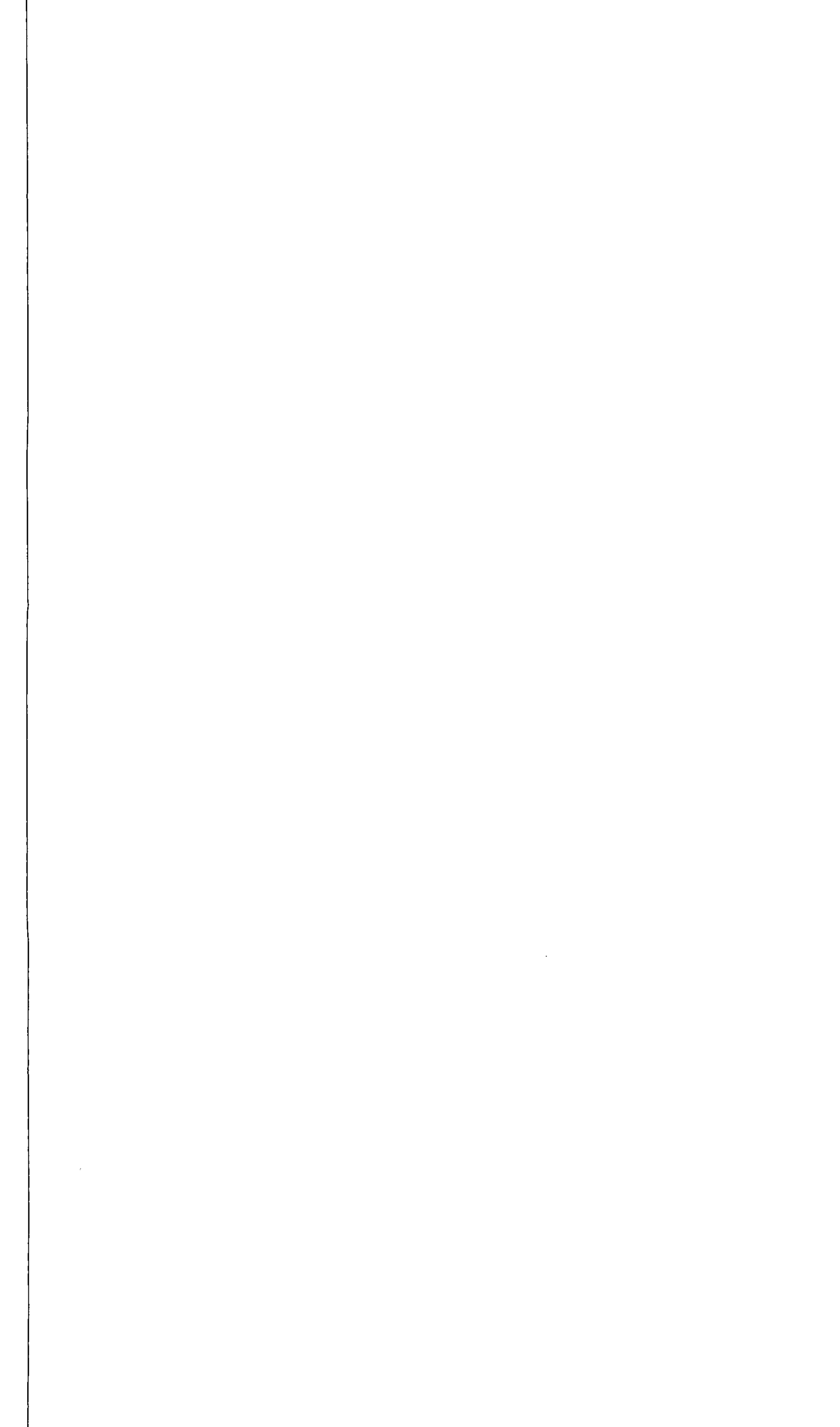




\subsection{ENVIRONMENTAL CONCERNS, ASSOCIATED LEGISLATION AND REGULATIONS, AND CONTROL OPTIONS}

This section discusses the Panel's review of the status of, and relationships between 1) each major category of environmental concern for which control methods may be needed, 2) pertinent regulations and/or legislation under which regulations may be anticipated, and 3 ) control options, whether available, under development, or in need of development. Seven sections follow which address:

- Air Emissions

- Liquid Discharges

- Solid Wastes

- Noise

- Subsidence

- Seismicity

- Hydrological Alterations.

The dynamic state of the geothermal energy industry made the Panel's evaluation extremely difficult. At this time, geothermal energy production is concentrated at a unique resource: the steamdominated field at The Geysers in California. The extent to which environmental problems at The Geysers are typical of those at liquiddominated sites is questionable. Similarly, the transferability of controls from The Geysers has not been fully established. Later, the extraction of Gulf Coast geopressured resources will present additional environmental concerns. 
The site specificity of environmental factors compounded further the task of assigning relative priorities to environmental concerns and, then, to research areas. Researchers have expanded the list of environmental concerns over the past several years, and are finding that the relative dimensions of the concerns vary widely from site to site. For example, intrusion of injected fluids into high quality aquifers appears improbable in the Imperial Valley, but is a major concern in the highly-fractured Raft River (Idaho) geothermal zone. Federal environmental regulations have not been developed for all the major categories of environmental concern. And one regulation--the application of prevention of significant deterioration (PSD) to $\mathrm{H}_{2} \mathrm{~S}$ emissions--will be amended in response to a court decision. State and local regulations vary, and are often more stringent than their federal counterparts. Adequate data bases are the foundation for reasonable regulations in all areas of concern, yet they are completely absent in the case of geothermal solid wastes. Several federal laws exist which may affect the siting of geothermal energy facilities. These include the Coastal Zone Management Act, the Wetlands Protection Act, the Historical Preservation Act, the Endangered Species Act, the Floodplain Management Act, the Rivers and Harbors Act, the National Environmental Protection Act, and the Geothermal Steam Act. In general, these laws impose anticipatory controls on geothermal development in that they affect the siting of 
energy facilities and do not require remedial application of control methods .

\subsection{Air Emissions}

\section{Problem}

Hydrogen sulfide $\left(\mathrm{H}_{2} \mathrm{~S}\right)$ has been and remains a major environmental concern of geothermal energy development. The offensive nature of $\mathrm{H}_{2} \mathrm{~S}$ odor is a greater cause of concern than its toxicity at the observed levels of concentrations of geothermal sites. Concentrations in air of 30 parts per million (ppm) or above are toxic while the odor threshold is only $0.0007-0.0032 \mathrm{ppm}$.

In the few states where $\mathrm{H}_{2} \mathrm{~S}$ standards exist, they are ambient standards based upon odor rather than known health or ecological effects. The standards are not uniform, varying from $0.003 \mathrm{ppm}$ (1-hour average) in most of New Mexico to $0.03 \mathrm{ppm}$ (1-hour average) in California. There is no federal $\mathrm{H}_{2} \mathrm{~S}$ ambient standard and this has led to the development of diverse state standards.

The problem of $\mathrm{H}_{2} \mathrm{~S}$ emissions from geothermal operations originated and continues to be focused at The Geysers power generation site in Northern California. The state ambient standard of $0.03 \mathrm{ppm}$ has been translated into allowable emissions that will be increasing1y restrictive as generating capacity expands. The problem is compounded at The Geysers by the fact that the first 500 megawatts (MW) of generating capacity was built without $\mathrm{H}_{2} \mathrm{~S}$ controls and thus has required retrofitting. 
Sources of $\mathrm{H}_{2} \mathrm{~S}$ emissions include well drilling, venting and cleanout, power plant operation, and steam stacking. Steam stacking occurs during plant shutdowns at vapor-dominated (steam) resources. In general, power plant emissions are the most significant source of $\mathrm{H}_{2} \mathrm{~S}$, with steam stacking second, and miscellaneous we11 emissions last.

It is expected that $\mathrm{H}_{2} \mathrm{~S}$ emissions will necessitate control at many, if not most, geothermal development sites, although it appears that the quantities emitted will vary greatly from site to site. Most cases will differ from The Geysers in that other resources are liquid-dominated rather than vapor-dominated (steam). If liquids are flashed, as is expected in most developments, then $\mathrm{H}_{2} \mathrm{~S}$ controls developed for The Geysers situation may be applicable to the steam fraction. On the other hand, control options may be broadened for liquid-dominated resources by offering the opportunity to treat the liquid stage before flashing. If the liquid is not allowed to flash during heat transfer, the opportunity also exists for closed-cycle operation (i.e., injecting the liquid back to the reservoir with little or no emission of gases).

Other substances may be emitted to the atmosphere during geothermal operations. These substances include carbon monoxide ( $\mathrm{CO}$ ), ammonia $\left(\mathrm{NH}_{3}\right)$, radon, hydrocarbons, mercury vapor, and boron. Al1 of these originate as components of the geothermal reservoir fluid. None has yet been shown to be of environmental significance, but the 
possibility exists, particularly for those that may be considered hazardous, such as radon and mercury.

\section{$\underline{\text { Regulations }}$}

The principal authority for regulation of air pollution is the Federal Clean Air Act, as amended by the Clean Air Act Amendments of 1977. In general, the Clean Air Act regulations are implemented by the states through State Implementation Plans required by the Act and approved by the Environmental Protection Agency.

Sections of the Clean Air Act that may have impacts upon geothermal development are:

- Section 107 - State establishment of Air Quality Control Regions; EPA establishment for interstate regions.

- Section 108 - EPA Publication of air quality criteria.

- Section 109 - EPA promulgation of national primary and secondary ambient air quality standards (now includes particulates, sulfur dioxide, nitrogen oxides, hydrocarbons, ozone, lead, and carbon monoxide); standards are effects-based.

- Section 110 - States establish implementation plans to meet standards; plans may include source emission limits.

- Section 111 - EPA establishment of New Source Performance Standards (emission limits) for any pollutant for specific stationary sources, standards are technology-based. States must then establish emission limits for same constituents from existing sources.

- Section 112 - EPA establishment of emission standards for hazardous air pollutants for specified sources; mercury, asbestos, beryllium, and vinyl chloride standards now exist for certain sources; none yet for geothermal.

- Section 122 - EPA must specifically review and may regulate radioactive pollutants, cadmium, arsenic, and polycyclic organic matter. 
- Sections 160-169 - establishes requirements to prevent significant deterioration of air quality in clean air areas.

- Section 169A - EPA establishes requirements toward remedying visibility impairment in Federal Class I areas where visibility is an important value.

EPA currently has no plans to add any of the known geothermal air pollutants to the list of criteria pollutants and, hence, to establish a national ambient air quality standard for any of them. However, a state may add geothermal air pollutants to its 1 ist of controlled pollutants as some have already done for hydrogen sulfide. These states include, California, New Mexico and Hawaii. EPA may develop New Source Performance Standards (NSPS) for hydrogen sulfide and perhaps other emissions from geothermal operations. Any geothermal power plant that would have the potential to emit 250 tons or more of $\mathrm{H}_{2} \mathrm{~S}$ per year would have to meet the permit requirements of EPA's existing regulations for the prevention of significant deterioration (PSD). This including, in most cases, a requirement for the application of best available control technology (BACT). In response to a recent court decision, however, EPA has proposed comprehensive amendments to the PSD regulations (see $44 \mathrm{FR}$ 51924, September 5, 1979). Among them is a provision that would in effect exempt from the BACT requirement, as well as other PSD requirements, any source that would emit only non-criteria pollutants in major amounts (44 FR 51953-54\$52.21 (i)(g)). A geothermal power plant would emit only $\mathrm{H}_{2} \mathrm{~S}$, a non-criteria pollutant in major 
amounts, if current indictions hold true. Whether EPA will make that provision is as yet uncertain.

\section{Status of Controls}

Among geothermal air emissions, only hydrogen sulfide has been of sufficient concern to date, to require control. So far, there is no evidence to indicate that other air pollutants will require control.

Virtually all of the pilot or ful1-scale demonstrations of geothermal $\mathrm{H}_{2} \mathrm{~S}$ removal technology have been at The Geysers power generation site. Several bench-scale development efforts are being carried out there and elsewhere. Of the demonstrated technologies, three show promise for commercial scale application. These are:

- Iron catalyst process

- Stretford process

- EIC process (developed by the EIC Corporation)

The iron catalyst and Stretford processes are "downstream" technologies, meaning they are applied to the turbine exhaust. The EIC process is applied to the raw steam "upstream" or ahead of the turbine. Upstream technologies have the advantages of 1) being able to control emissions during steam stacking (the process of venting the steam flow during power plant shutdown), 2) reducing the corrosivity of the steam to turbine blades and other power plant components, and 3) being able to control ammonia and boron emissions. 
The Stretford process is applied to the noncondensible gas ejector stream from a surface condenser. The stream is scrubbed with a regenerable aqueous solution containing sodium carbonate, sodium metavanadate, and anthraquinone disulfonic acid. Pure sulfur is produced by the process. A drawback of the process is that, although it can remove virtually all $\mathrm{H}_{2} \mathrm{~S}$ that it contacts, it cannot treat the $\mathrm{H}_{2} \mathrm{~S}$ dissolved in the condensate. This portion will be emitted at the cooling tower unless treated. It was originally thought that this would constitute less that 20 percent of the total $\mathrm{H}_{2} \mathrm{~S}$, but in practice it appears that it may be up to 40 percent. Thus, the condensate may also require treatment, perhaps with hydrogen peroxide.

The iron catalyst system has been applied at The Geysers to the older units with direct contact condensers. Ferric sulfate is added to the condensate cooling water, oxidizing the $\mathrm{H}_{2} \mathrm{~S}$ contained in the aqueous phase. The noncondensible gases are ducted into the cooling tower and scrubbed by the falling water. Ferric ions are regenerated and sulfur is produced. However, the sulfur sludge is impure and presents a toxic solid waste problem. The $\mathrm{H}_{2} \mathrm{~S}$ removal efficiency for the iron catalyst system has been low (around 60 percent), but it has been improved to greater than 90 percent by adding hydrogen peroxide and sodium hydroxide to the process.

The EIC process is the only demonstrated process whose development has been supported, in part, by government funding. The recently completed one-tenth scale demonstration at The Geysers was very 
successful, removing more than 95 percent of the $\mathrm{H}_{2} \mathrm{~S}$ from the raw steam. The steam is scrubbed with copper sulfate to produce copper sulfide and ammonium sulfate. Copper sulfate is regenerated from the copper sulfide and the cleaned steam is sent to the turbine.

There is no certainty that any of the above technologies will be consistently successful and/or economical in all applications. A central question is how easily the processes being tested on vapordominated resources can be transferred to the more prevalent liquid-dominated resources. For that reason, other $\mathrm{H}_{2} \mathrm{~S}$ removal technologies are being examined. Some of these are:

- electrochemical oxidation (brine)

- Dow oxygenation process (brine)

- activated carbon/metal catalyst (brine/steam).

\section{Conclusions and Recommendations}

Hydrogen sulfide has been and remains a major environmental concern of geothermal energy development and utilization. It is recognized as a leading concern by both government and industry experts. The concern has been significant enough to interfere with geothermal development and expansion at some sites. Several states, including California, New Mexico, and Hawaii, have established $\mathrm{H}_{2} \mathrm{~S}$ ambient standards. However, existing control technology has not been demonstrated to consistently meet these standards and federal funding for research, development, and demonstration of new methods has faded. The problem is potentially a major barrier to geothermal development. 
The apparent reliance in the federal program on the EIC process for an ultimate solution is both premature and unwise.

Although the Panel recognizes that private industry will contribute to the improvement of $\mathrm{H}_{2} \mathrm{~S}$ control technology, the Panel recommends that the federal government support, at a significantly increased level, research, development, and accelerated commercial demonstration of control technologies for:

- $\mathrm{H}_{2} \mathrm{~S}$ power plant emissions

- $\mathrm{H}_{2} \mathrm{~S}$ steam stacking and well emissions. In addition, non- $\mathrm{H}_{2} \mathrm{~S}$ air emissions should be characterized and controls developed where necessary.

\subsection{Liquid Discharges}

\section{Problem}

The waste waters from geothermal operations that will be of the greatest environmental concern will be spent "brines" (the geothermal fluid from which heat has been removed). Of lesser concern will be condensate/cooling water, site runoff, and sanitary waste.

Spent brines and condensate that contain contaminants (e.g., dissolved metals) in potentially harmful quantities are likely to be subsurface-injected. Even if they are not environmentally harmful, they may be injected back to the reservoir as insurance against subsidence and reservoir depletion.

In some, perhaps many cases, spent geothermal brines may be surface-discharged. Circumstances conducive to surface discharge are: 
- high water supply demand in arid areas

- relatively high quality of geothermal water compared to surface water

- high cost of injection

- relatively low volume of waste water, such as in non-electric applications.

It also may be expected that runoff and sanitary waste waters associated with geothermal operations would remain in the surface water domain.

The environmental concern is probably greatest from injection with its potential for waste water migration or leakage to aquifers supplying water for drinking and other uses. The premise here is that, unlike surface water contamination, pollution of an aquifer may be permanent and virtually non-correctable once it has occurred. The potential danger is compounded by the fact that geothermal reservoirs are characteristically (except for the Gulf Coast geopressured zone) in geologically unstable areas where natural conduits, such as faults and fractures, are common.

Another important consideration in geothermal injection is that the quantities of injected water, particularly from power generation sites (or methane extraction sites in the geopressured case), will be enormous. Those quantities may be orders of magnitude greater than those of past experience, in oil and gas fields, for example. Surface discharges of spent geothermal fluid pose the potential for surface water pollution from the natural constitutents in the 
fluid and any added materials. The potential problems from the spent waters, runoff and sanitary wastes might be similar to those of an inorganic chemicals plant discharging to surface waters.

Regulations

The principal federal law governing water quality is the Federal Water Pollution Control Act Amendments of 1972. The law primarily protects surface waters by way of permits under the National Pollution Discharge Elimination System (Section 402). Adminstration of the System is by the states, upon EPA authorization. Industryspecific Effluent Guidelines may be promulgated under Sections 304 and 306. Permit conditions may then be based upon those guidelines. More restrictive permit conditions may be imposed based upon receiving Water Quality Standards (Section 303), if the tachnology-based Effluent Guidelines will not be sufficiently protective of receiving waters.

The Federal Safe Drinking Water Act mandated the establishment of an Underground Injection Control Program, also to be administered by the States, to protect drinking water aquifers. This program will also require injection permits whose issuance is based upon a prior analysis of the planned injection and an encompassing area of review for geological, hydrological, and man-made influencing factors. Well construction and monitoring requirements are prescribed. The regulations are now in the proposal stage. 


\section{Status of Controls}

Treatment technologies now exist to remove almost any constituent from waste water. With little modification, experts feel existing technologies can be transferred to the treatment of geothermal waste waters. Lower cost technologies such as chemical precipitation and flocculation, sedimentation, and filtration, generally are most useful in removing suspended materials. These are the technologies most likely to be used for treating geothermal waste waters. These technologies may be used prior to surface disposal of relatively high quality spent fluids or may be used to treat water prior to injection to prevent potential plugging of the injection system.

More sophisticated technologies that will remove dissolved salts characteristic of geothermal brines are typically expensive. For the large volumes of waste water associated with geothermal power production, the costs may be prohibitive. Such technologies include forced evaporation, ion exchange, reverse osmosis, and electrodyalys is. Only where mineral recovery may be profitable or where water for other uses is at a high premium are these technologies expected to be viable for geothermal operations.

\section{Conclusions and Recommendations}

Preventing contamination of both surface and subsurface water resources from brine injection or surface disposal represents a major concern of geothermal energy development and utilization in the eyes of both government and industry experts. Adequate waste water 
treatment technologies appear to be generally available, but, beyond primary treatment, may be too costly to be applied widely. It is more important to develop high rate injection technologies and monitoring techniques for injection that will ensure confinement of fluids that are environmentally harmful for very long periods. Planned federal funding for FY 1980 is at a very low level for waste water controls and for injection monitoring system development. The Panel recommends that the federal government assign high priority and enhanced funding to research on:

- Injection monitoring techniques

- Treatment and use of nongeothermal waters for injection to prevent subsidence and reservoir depletion.

The Panel further recommends that research support be provided to:

- Brine treatment

- In-line monitoring techniques

- Chemical and physical modelining/simulation techniques for predicting characteristics of brine constituents.

\subsection{Solid Wastes}

Problem

Solid wastes from geothermal operations are likely to be comprised mainly of the residual sludges of air and water treatment, scale from cleaning the fluid distribution and conversion networks, and the cuttings and drilling muds from production and injection we 11 drilling. Any or all of these wastes may in the future be classified as hazardous on the basis of hazardous waste criteria. If the wastes 
are determined to be hazardous they will be subject to restrictive regulations. The pollutant constituents in the treatment sludges will include metals, sulfur, and other inorganic materials from the geothermal fluid, plus treatment chemicals that may be added to aid energy extraction and reduce equipment deterioration. Drilling wastes will include rock cuttings and a variety of chemical materials in drilling muds.

The potential volume and characteristics of geothermal solid wastes are now largely unknown, although it is anticipated that very high generation rates will occur at some sites. Thus, the extent of the problem will not be known until adequate characterization studies are completed.

\section{Regulations}

The authority for federal control of solid wastes, both hazardous and nonhazardous, is the Resource Conservation and Recovery Act (RCRA) of 1976. Hazardous waste regulations were proposed in December 1978 regarding 1) the identification and listing of hazardous wastes, 2) standards applicable to generators of hazardous waste, and 3) performance standards for hazardous waste management facilities. Final regulations applicable to generators and transporters of hazardous wastes and also for notification of hazardous waste activity were recently published. Congress is currently temporarily excluding geothermal solid wastes from control under the hazardous waste regulations while EPA makes a study to determine 
whether these wastes are hazardous, how to manage them, and the costs of waste management. If geothermal wastes are determined not to be hazardous, their disposal will be regulated as nonhazardous solid wastes under Section 4004 of the Resource Conservation and Recovery Act, to be implemented by the individual states.

Authority for control of toxic materials in drilling muds may exist at the federal level in the Toxic Substances Control Act. In addition, several states now have regulations controlling solid waste disposal. California, for example, considers geothermal solid wastes as toxic, requiring their containment in an impervious secured landfill with leachate monitoring and treatment.

\section{$\underline{\text { Status of Controls }}$}

Methods, such as secured landfills, are available for managing solid wastes, including hazardous wastes. Evaluations have not been conducted on management options for geothermal wastes, however, and waste characterizations (which precede disposal evaluations) have not been undertaken. Following the completion of evaluations, management technology will be prescribed in solid waste management regulations. One of the main problems may be to find acceptable disposal sites within a reasonable distance from the geothermal operation. Waste management may be very costly for geothermal operations, particularly if the wastes are determined to be hazardous and disposal sites are not readily accessible. 


\section{Conclusions and Recommendations}

Solid wastes from geothermal energy development and utilization have not been adequately characterized. Until characterizations have been completed, definitive evaluations of solid waste management options are impossible. With the commercialization of liquid-dominated resources looming (these resources could generate large amounts of solid wastes), the Panel concludes that solid wastes bear a high priority and recommends greatly enhanced efforts to characterize them and to evaluate management options. The recommended study should include the following tasks and be performed from FY 1980 to FY 1982:

1) define physical and chemical characteristics of geothermal solid wastes

2) evaluate the applicability of current waste management practices to geothermal wastes

3) consider health and environmental effects of each management procedure

4) evaluate cost ( $\$ /$ ton) of each waste management procedure

5) recommend measures to adequately manage these solid wastes.

\subsection{Noise}

Problem

Well drilling and testing, steam venting and plant operation are the major sources of noise pollution. Well drilling and steam venting represent the greatest noise problems of geothermal development. Noise produced during system testing and venting originates from the direct escape of geothermal fluid from wellheads, separators, vents and bypasses in the fluid distribution system. The frequency of 
system testing or venting may decrease after the plant becomes operational. These noise sources will not cease, however, because additional wells must be drilled to support a level of energy production over the lifetime of a field.

Noise pollution presents a relatively minor problem to geothermal energy development when compared with air pollution, water pollution, and solid waste. However, noise pollution can be significant enough to affect siting decisions for geothermal facilities.

\section{Regulations}

The Noise Control Act of 1972 provides for federal regulatory authority over noise from aircraft, railroads, construction and transportation equipment, motors, engines, and electrical or electronic equipment. Control of noise pollution from other sources is generally left to state and local governments. However, the Act encourages federal agencies to limit noise levels at federal facilities and authorizes EPA to coordinate those efforts. The U.S. Geological Survey, for example, limits noise from geothermal operations on federally leased land to 65 decibels-A scale (dBA) at the lease boundary or one-half mile from the sound, whichever is greater. In addition, the Occupational Safety and Health Administration (OSHA), although it does not actually limit the noise source, specifies that no worker be subject to $115 \mathrm{dBA}$ noise for more than 15 minutes or to $90 \mathrm{dBA}$ noise for more than eight hours, without ear protection. 


\section{Status of Controls}

Control of noise pollution from geothermal sites may be accomplished by prevention, shielding, or attenuation of the noise. There are numerous types of noise abatement equipment which can be installed relatively inexpensively. These include rock-filled or water-filled chambers, baffled sound-absorbent mufflers, and large twin-cylinder centrifugal expansion towers. Noise pollution can also be alleviated by careful siting, or keeping the site away from the affected population.

\section{Conclusions and Recommendations}

Noise abatement equipment exists that can adequately control the noise generated by geothermal energy development. This equipment can range from simple shielding techniques to sophisticated centrifugal expansion towers, but in either case, the equipment cost is small compared to other pollution abatement equipment.

The proposed federal budget allows for $\$ 50,000$ for noise control technology development in FY 1980. Additional research efforts for noise control are not recommended by the Panel.

\subsection{Subsidence}

\section{Problem}

Subsidence or sinking of the land may be caused during geothermal energy development by removing large amounts of fluid from the ground. Subsidence presents a major concern where the topography of the neighboring land is very level, where bodies of water may be 
affected, or where there are nearby surface improvements. For example, a small amount of subsidence in the Imperial Valley may cause major irrigation and drainage problems. However, subsidence in naturally hilly locations may cause only minor or insignificant problems.

The amount of subsidence that occurs when a given volume of fluid is withdrawn and not replaced is dependent upon the geological formations in the area of the site. If the surface land is supported in part by fluid, subsidence will be greater than in areas where the surface is totally supported by rock formations.

Subsidence could present a major concern if geopressured resources near the Gulf Coast are utilized because a large amount of land near this region is presently only a few feet above sea level.

$\underline{\text { Regulations }}$

For geothermal developments on leased federal lands, USGS Geothermal Operations Order No. 4 states: "Surveying of the land surface prior to and during geothermal resources production will be required by the (United States Geological Survey (USGS)) for determining any changes in elevation (on and around) leased (federa1) 1ands. Lessees shall make such resurveys as required by the (USGS) to ascertain if subsidence is occurring. Production data, pressures, reinjection rates, and volumes shall be accurately recorded and filed monthly with the (USGS). In the event subsidence activity results from the production of geothermal resources, as determined by surveys 
by the lessee or a governmental body, the lessee shall take such mitigating actions as are required by the lease terms and by the (USGS).

If subsidence is determined by the (USGS) to present a significant hazard to operations or adjoining land use, remedial action may be required, including, but not 1 imited to, reduced production rates, increased injection of waste or other fluids, or a suspension of production."

\section{Status of Controls}

Only two approaches, or a combination of them, are available to control subsidence from geothermal fluid extraction. The first approach is to monitor the 1 and near the sites and reduce or terminate production if significant subsidence occurs. The second approach is to inject the geothermal fluid that was withdrawn from the reservoir. In most cases, injection may be the more appropriate environmental cleanup approach because it involves the disposal of a major source of the air, water, and land pollution from geothermal energy systems. If injection is used to prevent subsidence, nearby high quality aquifers will have to be monitored to protect them from contamination by the injected fluid. A more detailed discussion of the problems of injection with respect to water quality was presented in Section 2.2, Liquid Discharges.

Conclusions and Recommendations

In most cases, subsidence will not be a major concern of geothermal energy development. The lack of adequate characterization 
and prediction measures, however, may prevent utilization of resources at sites where other land uses would be affected. The Panel concludes, accordingly, that subsidence characterization prediction and control retain a high priority for research.

The federal government is currently supporting both site monitoring and predictive model development for subsidence. This support should be increased to include research of subsidence characterization, prevention and control methods.

\subsection{Seismicity}

Problem

Many geothermal resources are located in regions with a high frequency of naturally occurring seismic events. There has been concern expressed as to whether the withdrawal and/or injection of geothermal fluids may enhance the rate of microseismic events or even trigger a major earth movement. Studies have shown that high pressure injection of large volumes of geothermal fluid can increase the frequency of microseismic events. However, it is not known what pressures and volumes are required to increase the frequency of events or whether a significant tectonic release can result from the lubrication of a major fault.

\section{Regulations}

The installation of seismographs or other instruments in producing geothermal areas for the purpose of detecting potential seismic activity may be initiated from time to time by appropriate 
public agencies. For geothermal developments on leased Federal land, the USGS Geothermal Resource Operations Order No. 4 states: "Where induced seismicity caused by the production of geothermal fluids on leased federal lands is determined to exist, the (USGS) may require the lessee to install such monitoring devices as necessary to adequately quantify the effects thereof. If induced seismicity is determined to represent a significant hazard, remedial actions may be required by the (USGS), including, but not limited to, reduced production rates, increased injection of waste or other fluids, or suspension of production."

\section{Status of Controls}

There are two approaches that can be taken to minimize the probability of significant seismic activity caused by geothermal energy development. The first involves careful site selection, either avoiding major faults or locating at sites that have the least likelihood of enhancing seismicity. This task can be aided by performing extensive geological surveys and microseismic studies of the proposed sites.

The second approach to minimize induced seismicity is to monitor the geothermal area and stop production or injection if it is shown that geothermal production has caused unacceptable seismic activity. This approach involves making baseline measurements for several years of naturally occurring seismic events in terms of depth of earthquake foci, duration of event, force of event, and frequency of events. 
Once these data are obtained, seismic activity during geothermal production can be compared to naturally occurring events and the source of the activity can be evaluated. If it is shown that the source is the geothermal production, then production can be reduced or stopped, or injection techniques modified (i.e., altering flow rate and/or pressure).

\section{Conclusions and Recommendations}

Geothermal energy development has not been shown to be a contributor to significant earthquake activity in the U.S. It is not certain that this record will continue, as significant development has not yet occurred in earthquake-prone areas. It has been shown (e.g., at The Geysers) that geothermal production may cause an increased frequency of minor seismic events. Even this enhanced microseismicity may be reduced by careful site selection, and the chance of a significant earth movement can probably be reduced by monitoring and production curtailment techniques. In short, in most cases, concern of induced seismicity should not present a major obstacle to the commercialization of geothermal resources.

The federal funding for geothermal related seismic research is approximately one million dollars for FY 1979 and \$750,000 FY 1980. The Panel feels that continued funding at the 1979 level should be maintained to adequately identify and characterize induced seismicity and to evaluate control techniques. 


\subsection{Hydrological Alterations}

Problem

Possible detrimental effects of geothermal energy development on geological formations and hydrological communication between them represents an environmental concern that, if unattended, may retard or prevent the commercialization of some geothermal resources. It is suspected that geothermal development may effect surface features such as hot springs, fumaroles, mud pots and geysers or may deplete reservoirs utilized for public water supply, agricultural, recreational, and many other purposes. Significant environmental concern for possible hydrological alterations caused by geothermal development have been expressed for the Island Park area adjacent to Yellowstone National Park as well as Mammoth Park, Mono-Long Valley, and Volcanic Park.

Deep ground water systems associated with geothermal resources are complex and largely unknown. Interconnections between geothermal resources and surface features are difficult to understand or even identify. Studies of these systems require drilling of shallow and/or deep wells and relatively large financial investments. In spite of the costs involved, research and study are essential if proper leasing decisions or drilling strategies are to be made.

\section{Regulations}

The Underground Injection Regulations, by preventing injection to certain aquifers and allowing it to others, may have a significant effect on subsurface water movement in public water supply areas. 
Otherwise, specific regulations do not exist for controlling hydrological alterations (e.g., changes in pressure head, temperature, water quality, and natural discharges) resulting from geothermal development, particularly from fluid. Some areas with significant geothermal surface features, such as Yellowstone National Park and Mt. Lassen National Park, are stated as being off-limits to development under the Geothermal Steam Act. In addition, the National Environmental Policy Act requires evaluation of the impacts of geothermal development on unique features, such as hot springs or shallow ground water. Additional legislation requiring hydrological evaluation prior to geothermal development near certain unique lands and protection of hot springs are being proposed by federal and state governments.

\section{Status of Controls}

As in the case of subsidence or seismicity, the only approaches available to control hydrological alterations are siting and monitoring in conjunction with possible termination of operations. Where geothermal development is likely to have unacceptable adverse effects on hot springs, geysers, or other surface indicators of geothermal resources, the land should be excluded from federal leasing. If leasing is permitted, hydrological studies may be conducted to determine well location of least impact and monitoring wells may be drilled to aid prediction of significant alterations in the hydrological system. 


\section{Conclusion and Recommendations}

If proposed legislation is enacted, federally supported hydrological evaluations may be required of proposed geothermal development sites. The cost of these evaluations may be very high at some sites.

The panel is not prepared at this time to recommend significantly increased efforts aimed specifically at developing predictive tools for hydrological alterations. Further study is, however, required in anticipation of future legislative constraints. 

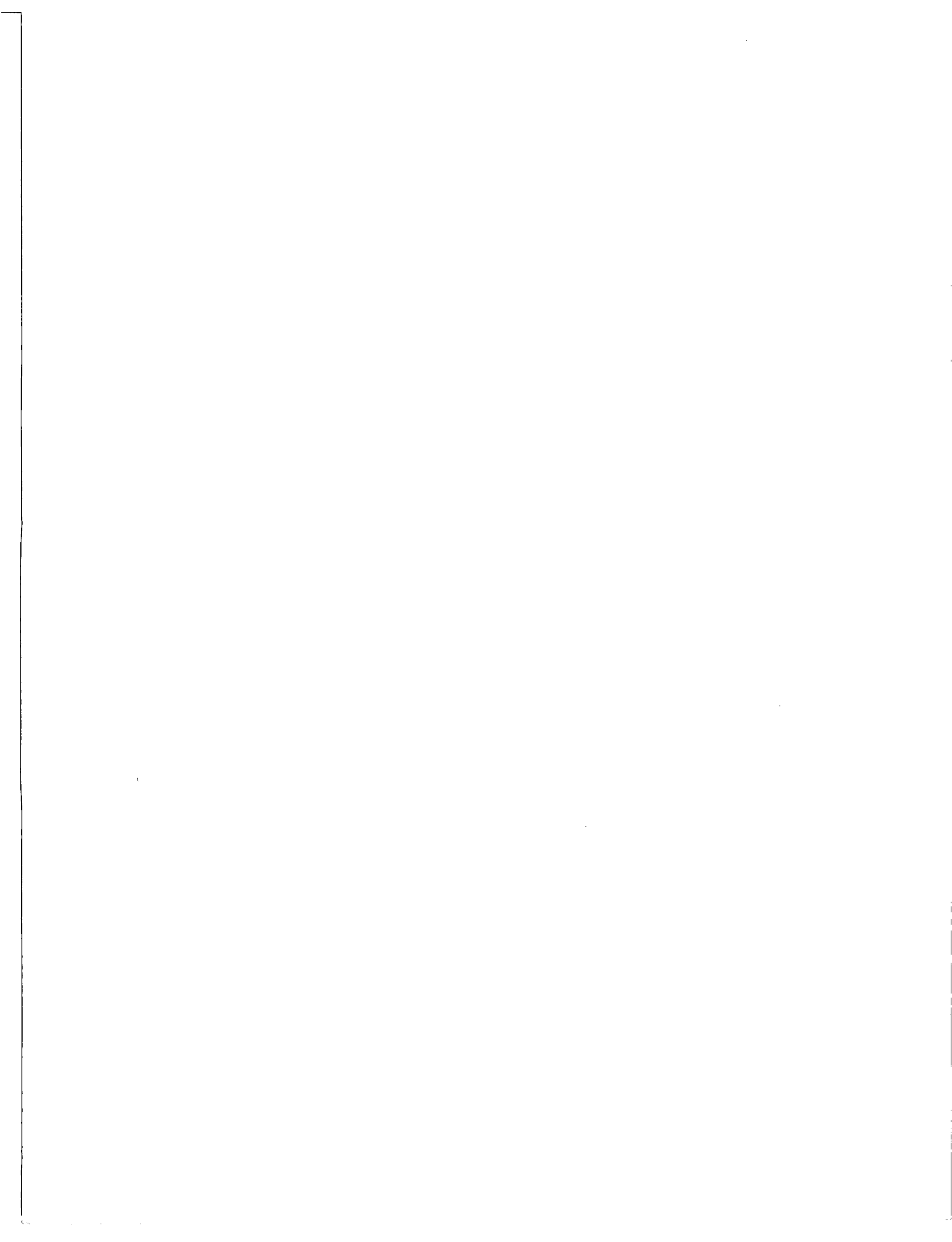


\subsection{RECOMMENDATIONS OF THE ENVIRONMENTAL CONTROLS PANEL}

\subsection{Priorities for Research in Environmental Controls}

In its review of geothermal environmental concerns, legislative and regulatory ramifications, and control technologies or methods, the Environmental Controls Panel identified 16 control-related research areas; at least some research is underway in nearly every area. A process was established for evaluating the relative significance of the 16 research areas to the availability of controls for geothermal energy systems. The views of several industry experts were solicited in addition to those of government experts on the Panel.

The 16 control-related research areas identified by the Panel extend beyond the several control technology categories. Included as well are control-related methods or devices (such as injection well monitoring), modeling and simulation techniques, and residuals characterization and control methods assessment (such as needed for promulgation of reasonable solid waste regulations).

The 16 research areas are presented in Table 3-I according to their respective category of environmental concern. No research areas have been identified for hydrological alterations.

The Panel, working with several experts from industry, evaluated the relative priorities of the identified control-related research areas. To aid its deliberations, the Panel applied a modified Delphi 
TABLE 3-I

CONTROL-RELATED RESEARCH AREAS

BY GEOTHERMAL ENVIRONMENTAL CONCERN

$\underline{\text { Air Emissions }}$

- $\mathrm{H}_{2} \mathrm{~S}$ Controls for Power Plants

- $\mathrm{H}_{2} \mathrm{~S}$ Steam Stacking and Well Emission Controls

- Characterization and Controls for Non- $\mathrm{H}_{2} \mathrm{~S}$ Air Emissions (Boron, Ammonia, Carbon Monoxide, Hydrocarbons, Mercury and Arsenic)

- Controls for Radon

Liquid Discharges

- Injection Monitoring Systems

- Controls for the Treatment and Use of Non-Geothermal Waters

- Brine Treatment

- Chemical and Physical Modeling/Simulation Techniques

- In-line Monitoring

Solid Wastes

- Solid Wastes Characterization and Management Methods Evaluation

- Solid Waste Management Methods Development

Noise

- Noise Control

Subsidence

- Subsidence Prevention, Predicition, and Control

- Induced Subsidence Characterization

Seismicity

- Induced Seismicity Identification and Characterization

- Induced Seismicity Controls Development 
technique to rank the 1 isted research areas. The criteria utilized in the ranking exercise are presented below:

- Availability of adequate controls

- Requirements for controls under existing/pending regulations

- Cost to develop controls

- "Visibility" (i.e., public perception of the significance of an environmental concern)

- Timing of affected sites

- Cost of control

- Megawatts affected

- Number of sites affected

- Repairability of environmental effect

- Severity of environmental impact

Later, the Panel relaxed its numerical ranking in favor of categorizing the research areas into three groups: "top", "medium", and "bottom" priority. The results of this grouping are presented in Table 3-II. The research areas deemed to be highest priority included certain aspects of air emissions, liquid discharges, subsidence, and solid wastes. The Panel recommends that enhanced funding be provided to each of these areas except methods for subsidence prevention, prediction and control.

of the seven research areas considered highest priority, development of controls for hydrogen sulfide emitted from normal power plant operations, steam stacking, and miscellaneous well 
TABLE 3-II

PRIORITIES FOR ENVIRONMENTAL CONTROLS RESEARCH

Top Group

Hydrogen Sulfide Controls for Power Plants

Injection Monitoring*

Hydrogen Sulfide Steam Stacking/

Well Emissions Controls

Solid Waste Characterization and

Management Evaluation

Non- $\mathrm{H}_{2} \mathrm{~S}$ Gaseous Emissions Characterization and Development of Controls

Treatment and Use of Nongeothermal Waters*

Methods for Subsidence Prevention, Prediction and Control*

\section{Middle Group}

Brine Treatment

In-line Monitoring

Chemical and Physical Modeling/Simulation

Techniques

Solid Waste Management Technology Development

Induced Seismicity Identification and Characterization

Induced Subsidence Characterization*

\section{Bottom Group}

Induced Seismicity Controls

Noise Controls

*Injection Technology-related 
emissions was consistently mentioned as bearing a high priority. Non-hydrogen sulfide emission controls (other than for radon) were also rated in the most critical group. Three of the top areas involved treatment and disposal of geothermal waters and nongeothermal makeup waters. Specifically, development of methods for injection monitoring, techniques for the treatment and use of nongeothermal waters as makeup in reinjection programs, and control methods for reducing the risk of subsidence are included in the top priority group. (The importance of improved injection technology for the disposal of spent fluids was also noted by the Panel.) The characterization of solid wastes and the evaluation of methods for proper management of hazardous constituents were included in the top priority group.

There was a clear consensus that several research areas receive low priority for federal funding. Included in the bottom group by the Panel are seismicity controls (on the basis that the best control is avoidance) and noise controls (on the basis that adequate muffing devices are available). A seventeenth research area, flow test residuals controls, was considered and rejected by the Panel. The Panel felt that control during the flow tests can be handled by available techniques for solids and liquids or will be of such short duration that control is unnecessary.

The remaining, middle priority, group includes brine treatment, in-1ine monitoring, chemical and physical modeling/simulation 
techniques, solid waste management, radon controls, and seismicity and subidence characterization.

It should be noted that the Panel ascribed a moderate priority to a few areas considered to be less important by some industry experts. These are radon control and seismicity and subsidence characterization. These differences are not viewed by the Panel as a major cause for alarm. Neither the Panel nor industry felt any of these areas are high priority items, and neither the Panel nor industry urged that no consideration be given these areas. The Panel's recommendation that somewhat greater attention be given these areas may be attributed to the Panel's longer time horizon and to its penchant for comprehensiveness.

\subsection{Other Recommendations}

The Panel recommends that federal research on environmental controls for geothermal energy systems be closely coordinated on a interagency basis. The need for this is aparent when the disparate roles of various government agencies are considered:

- Environmental Protection Agency: Establishes programs, policies, and regulations to protect the environment

- Department of Energy: Conducts research on all aspects of geothermal energy commecialization activities including compliance with legislative environmental mandates, and leasing of potential geothermal lands

- Department of Interior: Conducts leasing and lease management programs for geothermal resources, protects or maintains fish and wildlife, national parks, lands, and waters, and conducts supporting research 
- Department of Agriculture: Conducts leasing programs (in conjunction with DOI) for geothermal lands

- Department of Defense: Controls use of some federal lands and resources.

In the absence of broad coordination among these agencies, controls-related environmental research can be inefficient, at best. Sharing data on emission, environmental impacts, and the performance of controls is essential to a coordinated controls development research program. Any lesser linkage would invite delays in commercialization and waste of federal resources. Specifically, the Panel recommends :

- Coordination among key agencies through the Panel mechanism for a federal research strategy for environmental control

- Increased coordination through the Panel mechanism with industry and environmental groups on controls-related issues

- Joint monitoring of production sites on a continuing basis for the purpose of developing a better understanding of environmental concerns and controls. 


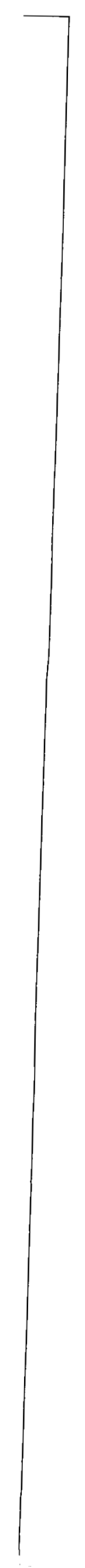


$\underline{\mathrm{D}-12}$

S. W. Gouse

R. Greeley

W-50

R. Ouelette

L. Thomas

W-50 Data Files (12)

W-51

A. Ghovanlou

W-53

T. Wright

W-54

E. Krajeski

S. Lubore

$\mathrm{W}-56$

P. Clifford

B. Fuller

W-58

L. Duncan

G. Erskine

$\mathrm{W}-80$

L. Cain

F. Eldridge

R. Foreman

L. Gsellman

R. Rifkin

M. Scholl

E. Sharp

W-81

R. Kalagher

R. Lay

W-82

P. Walker

W-83

E. Jamgochian

J. Stone

W-84

A. Autio

S. Lewis
W-85

R. Bjustrom

J. Caskey (35)

A. E1 Sawy

D. Entingh (20)

E. Goodwin

E. Hughitt

W. Jacobsen

M. Keimig

L. Kenkeremath

M-T Leth1

A. Lopez

D. Medville

C. Moncrief

E. Neham

M. Neuworth

R. Pfundstein

S. Rifkin

B. Walker

W-86

N. Coates

B-50

B. Cookson

B-52

S. Etienne

Metrek Library

(1)

Document Control (5)

Sponsors

Department of Energy

Dr. Fred Abel (50 Copies)

Division of Geothermal Energy

12th \& Pennsylvania Avenue

Federal Building

Room 7118

Washington, D. C. 20585

Mr. Colton We1rich ( 1 Copy)

Office of Procurement Operations

400 First Street, N. W.

Washington, D. C. 20585

Approved for Release $\frac{60 \mathrm{~g}}{\text { Project Leader }}$

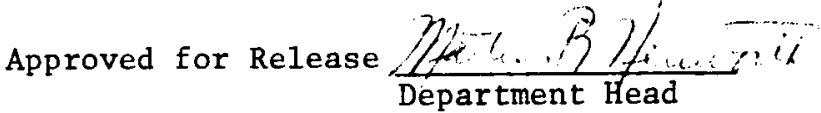

